\title{
Knowledge and Perception of Stroke among at Risk Medical Out-Patients in a Tertiary Health Institution in Nigeria
}

\author{
${ }^{1}$ A. O. Ajayi and ${ }^{2}$ O. O. Ojo \\ Departments of 1 Medicine and ${ }^{2}$ Community Health, Federal Medical Center, Ido-Ekiti, Nigeria \\ Reprint requests to: Dr. A. O. Ajayi, Department of Medicine, Federal Medical Center, P. M. B. 201, Ido-Ekiti, \\ Nigeria.E-mail: dejiajayi2@yahoo.co.uk
}

\begin{abstract}
Background: Patients who recognize their increased risk of stroke are more likely to engage in stroke prevention practices than those who do not.

Method: All patients attending medical out-patient clinic of the Federal Medical Center, Ido, Ekiti-State, Nigeria between January 2004-December 2004 were recruited into the screening process following their verbal consent. A set of questionnaire was administered to collect data.

Results: A total of 155 patients were studied having satisfied the inclusion criteria. The mean age of the patients was $58.4 \pm 18.7$ years. Majority of the patients indicated paralysis of one side of the body as the most common symptom of stroke. Patients with higher education $\mathrm{p}=0.002$ and men $\mathrm{p}=0.004$ were more aware of their increased risk factor for stroke than those with low education and women.

Conclusion: Perception about stroke among the at risk medical out patients as found out in this study indicates that more health education both at the community and the hospital is very vital to reducing the prevalence, recurrence, disability and mortality of stroke. Health providers are enjoined to communicate information about stroke risk to their patients.
\end{abstract}

Key words: Stroke, risk factors

\begin{abstract}
Résumé
Introduction : Des patients qui sont capable de savoir que leur risque d'une attaque augment sont très vraisemblabe d'engager des practiques de la préventions des attaques plus que ceux qui ne sont pas.

Méthodes : Tous les patients qui viennent consulter au centre médical des consultations externes du centre hospitalier fédéral Ido, l'Etat d'Ekiti, Nigéria entre le janvier 2004 au décembre 2004 ont été récrutés dans un processus d'un test à la suite de leur consentement verbal. Une parure de questionnaires ont été préparé afin de collectionner des données.

Résultats : Un total de 155 patients ont été étudiés après avoir satisfait des critères requis. Moyen d'âge des patients était 58,4+- 18,7 ans. La plus grande partie des patients ont montré la paralysie dans un côté du corps comme un symptôme d'attaque le plus ordinaire. Des patients avec un niveau d'enseignement supérieur. $\mathrm{p}=0,002$ et sexe masculin $\mathrm{p}=0,004$ ont été plus conscient des facteurs ménant à l'augmentation de leur risque d'attaque plus que ceux avec un niveau d'enseignement inférieur et sexe féminin.

Conclusion : La perception concernant l'attaque parmi des malades avec des risques d'attaque dans un centre hospitalier des consultation externes comme indiqué dans cette étude a montré que plus des renseingnements supplémentaires dans le domaine de la santé dans la communauté et dans l'hôpital les deux est très important afin de réduire la fréquence, récurrence, infirmité et la mortalité à travers l'attaque. Des médecins sont priés de passer des informations sur l'attaque et le risque d'attaque aux patients.
\end{abstract}

Mots-clés : Attaque, facteurs de risque

\section{Introduction}

Animal studies of cerebral ischaemia suggest that the time window for effective therapeutic intervention may be only 4 hours ${ }^{1}$. Researches in humans support these data; the first proven treatment for acute stroke is efficacious when given within 3 hours of stroke onset $^{2}$. Despite these observations, the majority of stroke patients do not seek medical attention within 3 or even 6 hours of symptom onset. ${ }^{3}$ 
Research on health behaviour indicates that patients who perceive themselves to be at risk for stroke are more likely to engage in (and comply with) stroke prevention practices than those who do not ${ }^{4}$. However, persons at risk often tend to underestimate the possibility of an adverse health event. ${ }^{5}$ Primary prevention is also an important approach to substantially reduce the prevalence, recurrence, disability and mortality of stroke $\mathrm{e}^{6-9}$.

Although knowledge about stroke undoubtedly influences the time of presentation, no prior study in Nigeria has assessed high-risk patients' knowledge of stroke or how this knowledge affects their decision to seek medical care. The primary goal of this study was to determine the knowledge and perception about stroke amongst at risk medical outpatients.

\section{Subjects and Methods}

All patients attending the medical out-patient clinic of the Federal Medical Center, Ido-Ekiti., Nigeria from January 2004- December 2004 were recruited into the screening process following their verbal consents.

The screening process included the determination of their blood pressure (BP), body mass index (BMI), fasting blood sugar, serum total cholesterol, alcohol intake and smoking. At the end of the screening exercise, 155 patients were allowed into the study proper having satisfied the inclusion criteria [high blood pressure $(\mathrm{BP}>140 / 90) \mathrm{mmHg}$ plus one or more risk factors such as previous stroke, transient ischaemic attack, alcohol ingestion, smoking].

A set of questionnaire was administered on all the patients regarding patients' age, sex, marital status, educational level, about diabetes and hypertension, symptoms of stroke, and personal belief on stroke.

Descriptive and comparative statistical analyses were performed using the statistical program SAS version 6.12. Chi-square tests were used to assess the relationship between components of stroke related knowledge, demographic characteristics and selfreported risk factors.

\section{Results}

A total of 155 patients were studied; $87(56.1 \%)$ were males and 68(43.9\%) were females, giving a male: female ratio of $1.3: 1$. The mean age of the studied population was $58.4 \pm 18.7$ years. $29(18.7 \%)$ of the patients were illiterates, $42(27.1 \%)$ had primary education, $31(20.0 \%)$ had secondary education and $53(34.2 \%)$ had tertiary education.

\section{Knowledge of stroke symptoms}

Eighty-seven $(55.6 \%)$ of the respondents indicated paralysis of one side of the body as the most common symptom of stroke, weakness of one side of the body was identified by $42(27.1 \%)$ of the respondents, sudden difficulty in speaking, understanding and reading was identified by $11(7.1 \%)$ of the patients. All the respondents were able to list at least one stroke symptom. Majority of the respondents were able to list 2 or more symptoms of stroke (Table 1).

\section{Knowledge of risk factors}

High BP was the most common risk factor identified by the respondents $94(60.6 \%)$. Previous history of stroke was identified by $25(16.1 \%), 19(12.3 \%)$ identified diabetes mellitus; high serum cholesterol level and family history of stroke were identified by 5 respondents $(3.2 \%)$ each. Recurrent history of chest pain/angina and smoking were identified by 2 respondents each $(1.3 \%)$. None of the respondents could identify alcohol as a risk factor.

\section{Concern about the possibility of developing a stroke}

One hundred and two $(65.8 \%)$ of the respondents never had the concern about the possibility of developing stroke, 25(16.1\%) sometimes thought of it, $19(12.3 \%)$ occasionally and $9(5.8 \%)$ always had the concern.

Table 1: Knowledge of stroke symptoms among 155 at risk medical out-patients

\begin{tabular}{ll}
\hline Knowledge of stroke symptoms & No. (\%) \\
\hline Paralysis of one side of the body & $87(55.6)$ \\
Weakness of one side of the body & $42(27.1)$ \\
$\begin{array}{l}\text { Sudden difficulty of speaking, } \\
\text { understanding or reading }\end{array}$ & $11(7.1)$ \\
Tingling sensations/numbness of one & $9(5.8)$ \\
side of the body & \\
Memory loss & $2(1.3)$ \\
Headache & $2(1.3)$ \\
Blurred/double vision & $1(0.6)$ \\
Dizziness/vertigo & $1(0.6)$ \\
Difficulty in swallowing & $1(0.6)$ \\
Chest pain or chest heaviness & - \\
Don't know & - \\
\hline
\end{tabular}

\section{Discussion}

This hospital-based study demonstrated aspects of public knowledge and perception about stroke. Majority $(54.2 \%)$ of the respondents had at least secondary school education.

The respondents were able to name at least one established stroke symptom compared to the study of Sung Sug Yoon et al, ${ }^{10}$ in which $85.5 \%$ of their respondents were able to name at least one stroke symptom. We found in this study that paralysis of one side of the body was the most common stroke symptom acknowledged by the majority of the respondents $(55.6 \%)$, while weakness of one side of the body ranked second $(27.1 \%)$. This compares to another report, $1^{11}$ which found in their hospital-based prospective study that weakness of one side of the body was the stroke symptom most frequently noted by patients. Contrary to another report, ${ }^{10}$ none of our respondents acknowledged chest pain or heaviness as a stroke symptom. None of the studied population failed to identify a risk factor. 
High BP was the most single risk factor commonly identified $(60.6 \%)$; this was similar to the findings of Ajayi et al in their study of perception of stroke among patients with stroke. ${ }^{12}$ Majority of our patients were aware of their increased risk factor for stroke, $65.8 \%$ of the patients never felt the concern about the possibility of their developing stroke in their life time, probably as a result of their ignorance. And on the perception of the likelihood of developing stroke, all were emphatic in rejecting it. In a similar study, ${ }^{10} 91.1 \%$ reported no, when asked about the chance of having stroke during their lifetime while $3.1 \%$ reported a high lifetime chance.

This study found that patients with higher education (above primary school) were more aware of their increased risk factor for stroke than those with low education and women. Older patients identified themselves as having a higher risk of stroke. This compares to another report, ${ }^{10}$ where older respondents identified themselves as having a lower risk of stroke. Patients who were informed by health care professionals that they had a stroke factor were more concerned about the possibility of having stroke than those who had not been told. Most patients showed a positive attitude to the possibility of stroke prevention

The level of knowledge and perception about stroke among at risk individuals in this study indicates that more health education, at community and hospital levels is vital to reducing prevalence, recurrence, disability and mortality of stroke. Health care providers should play more role in communicating information about stroke risk to patients.

\section{References}

1. Ginsberg MD. The validity of rodent brainischaemia models is self-sufficient. Arch Neurol
1996; 53:1065-1067

2. The NINDS rt-PA stroke study group. Tissue plasminogen activator for acute ischaemic stroke. N Engl J Med 1995; 333: 1581-1587

3. Williams LS, Bruno A, Rouch D, Marriott DJ. Stroke patients' knowledge of stroke. Stroke 1997; 28: 912-915

4. Krenter MW, Strecher VJ. Changing inaccurate perception of health risk: results from randomized trial. Health Psychol 1995; 14: 56-63

5. Janz NK, Becker MH. The health belief model: a decade later. Health Educ Qtly1984; 11: 1-47

6. Gorelick PB, Schneck M, Berglund LF, Feinberg $\mathrm{W}$, Goldstone J. Status of lipid as a risk factor for stroke. Neuroepidemiology 1997, 16: 107-115

7. Iso H, Jr Jacobs DR, Wentworth D, Neaton JD, Cohen JD. Serum cholesterol levels and six-year mortality from stroke in 350,977 men screened for the multiple risk factor intervention trial. $\mathrm{N}$ Engl J Med 1989, 320: 904-910

8. MacMahon S. Blood pressure and the prevention of stroke. J Hypertens (suppl) 1996;14: S39-S46

9. Wolf PA, D"Agostino RB, Kannel WB, Bonita $\mathrm{R}$, Belanger AJ. Cigarette smoking as a risk factor for stroke. The Framingham study. JAMA 1988; $295: 1025-1029$

10. Sung Sug Yoon, Richard FH, Christopher L, John W. Knowledge and perception about stroke among an Australian urban population. BMC Public Health 2001; 1: 14-16

11. Kothari R, Sauerbeck L, Jauch E, et al. Patients' awareness of stroke signs, symptoms and risk factors. Stroke 1977; 28: 1871-1875

12. Ajayi AO, Agboola SM, Oligbu GI, Ogunmoroti O, Ogunyemi D. Perception of stroke among patients with stroke. Nigerian Medical Practitioner 2005; 48: 56-58 